\title{
The role of limnological variables and habitat complexity in impacted tropical streams as regulatory factors on the flagellate protozoa community
}

O papel das variáveis limnológicas e da complexidade de habitats em riachos tropicais impactados como fatores reguladores da comunidade de protozoários flagelados

Janielly Carvalho Camargo ${ }^{1}$, Ludgero Cardoso Galli Vieira ${ }^{2}$ and Luiz Felipe Machado Velho ${ }^{1}$

${ }^{1}$ Graduate Course in Ecology of Inland Aquatic Environments, Research Nucleus in Limnology, Ichthyology and Aquaculture - Nupélia, State University of Maringá - UEM, Av. Colombo, 5790,

CEP 87020-900, Maringá, PR, Brazil

e-mail: janiellycamargo@hotmail.com; felipe@nupelia.uem.br

${ }^{2}$ Faculty of Planaltina - FUP, University of Brasília - UnB, University Area, 1, Vila Nossa Senhora de Fátima, CEP 73300-000, Planaltina, DF, Brazil

e-mail: ludbio@hotmail.com

\begin{abstract}
Objective: To contribute to the knowledge of patterns of spatial and seasonal distribution of composition and species richness of flagellate protozoa in tropical impacted streams and to identify which variables (physical and chemical or descriptor variables of habitat complexity) control these attributes in these environments. Methods: Samplings were performed in 10 tropical streams (5 urban and 5 rural) in two periods (summer and winter). Limnological variables were determined on the field (except for the concentration of nutrients), the habitat macrostructure was visually estimated in situ, using a quadrat and the species identification was performed in vivo, under optical microscope. Results: In total, 106 taxa were identified, the order Euglenida was that contributed most to the species richness, probably due to the high tolerance to environmental changes. Multivariate analyses (ANOSIM and MDS) evidenced significant spatial and seasonal differences both for composition and species richness. The Bioenv and Mantel Test indicated that the patterns of composition and richness were controlled by physical and chemical variables indicative of water quality $(\mathrm{pH}$, electrical conductivity, and concentration of nutrients). However, the species richness was also influenced by the habitat structural complexity and by its stability, which can be disturbed by the rainfall regime. Conclusions: The results showed that flagellate protozoa are sensitive to environmental changes, and thus can be used as efficient bioindicators of water quality, as has already been done with other aquatic organisms. Moreover, human activities that cause changes in the channel morphology of lotic ecosystems may determine the occurrence of flagellate species, once the simplification of the habitat structure leads to the reduction of species in the environment.
\end{abstract}

Keywords: habitat structure, water quality, impacted streams, protozooplankton, community ecology.

Resumo: Objetivo: Contribuir para o conhecimento dos padrôes de distribuição espacial e sazonal da composição e riqueza de espécies de protozoários flagelados de riachos tropicais impactados e ainda identificar quais variáveis (físicas e químicas ou descritoras de complexidade de habitat) regulam esses atributos nestes ambientes. Métodos: As coletas foram realizadas em 10 riachos tropicais (5 urbanos e 5 rurais), em dois períodos diferentes (verão e inverno). As variáveis limnológicas foram determinadas em campo (exceto a concentraçáo de nutrientes), a macroestrutura do habitat foi estimada visualmente in situ, com auxílio de um quadrat e a identificação das espécies foi realizada in vivo, sob microscópio optico. Resultados: Foram identificados 106 táxons e a Ordem Euglenida foi a que mais contribuiu para a riqueza de espécies, provavelmente, devido à sua alta tolerância às alteraçôes ambientais. Análises multivariadas (ANOSIM e MDS) evidenciaram diferenças espaciais e sazonais significativas tanto para a composiçấo quanto para a riqueza de espécies. A Bioenv e o Teste de Mantel mostraram que os padróes de composição e riqueza de espécies foram regulados pelas variáveis físicas e químicas da água descritoras da qualidade da água $(\mathrm{pH}$, condutividade elétrica e concentração de nutrientes). Entretanto, a riqueza de espécies também foi influenciada pela complexidade 
estrutural do habitat e por sua estabilidade que pode ser perturbada pelo regime de chuvas. Conclusóes: Em suma, os resultados obtidos mostraram que os protozoários flagelados são bastante sensíveis as alteraçóes ambientais e por isso podem ser usados como eficientes bioindicadores da qualidade da água, como já tem sido feito com outros organismos aquáticos. Além disso, ficou evidente que atividades antrópicas que causam mudanças na morfologia do canal dos ecossistemas lóticos podem determinar a ocorrência das espécies de flagelados, pois a simplificação da estrutura do hábitat acarreta a diminuição de espécies presentes no ambiente.

Palavras-chave: estrutura de habitat, qualidade de água, riachos impactados, protozooplâncton, ecologia de comunidade.

\section{Introduction}

Flagellate protozoa are found in almost every aquatic biotope, where play important role on the metabolism of these ecosystems, especially given their great ability of energy and matter transfer along aquatic food chains (Azam et al., 1983; Arndt et al., 2000), since when consumed by ciliate or zooplankton (Arndt, 1993; Weisse, 1990), they transfer to these organisms the energy obtained in the consumption of bacteria, virus, picophytoplankton, nanophytoplankton and dissolved organic carbon (Xu et al., 2005), reintroducing into the aquatic food webs the matter and energy that would be eliminated (Azam et al., 1983). Furthermore, the pigmented flagellates may expressively contribute with the primary production in aquatic ecosystems (Safi and Hall, 1997).

In general, this community can be controlled by both biotic and abiotic factors, such as food resource availability, predation pressure, $\mathrm{pH}$, electrical conductivity, dissolved oxygen, trophic state, and climatic seasonality (Pace and Funke, 1991; Arndt, 1993; Samuelsson et al., 2006; Araújo and Godinho, 2008; Camargo and Velho, 2011). Nevertheless, evidences have suggested that in tropical lotic environments flagellates are primarily controlled by seasonal variation of the rainfall regime (Araújo and Godinho, 2008; Camargo and Velho, 2011), which modifies the structure and metabolism of the environment and aquatic communities as well (Cushing and Allan, 2001). On the other hand, the water quality can also influence the distribution of these organisms, as reported by some authors (Jiang and Shen, 2005; Araújo and Godinho, 2008). In this way, it is essential to determine the major factors controlling the structure and dynamics of this community in these environments, in order to subsidize the elaboration of proposals for monitoring, management, conservation and restoration of these ecosystems, which have been extensively modified in the recent decades by the various uses and occupations of the land.
These studies can also prevent the loss of rare and endemic species, because lotic environments support a rich and highly specialized biota, by being unique, dynamic and complex systems (Giller and Malmqvist, 1998).

Despite this, most of studies on flagellate are quite limited since addressed this community as a black box, evaluating only its functional role in the ecosystem (Arndt et al., 2000). This occurs mainly because the fixation processes required for epifluorescence microscopy that produce cell deformation, not allowing the species identification (Arndt et al., 2000; Auer and Arndt, 2001). This is because most studies has no taxonomical detail (Arndt et al., 2000), which makes difficult to know the patterns of composition and richness of this community. Among the few studies in lotic environments with some taxonomic detail on flagellate protozoa community, stand out the studies developed by Carlough and Meyer (1989), Arndt and Mathes (1991), Weitere and Arndt (2003), Tikhonenkov and Mazei (2006), Kosolapova (2007), Araújo and Godinho (2008), Tikhonenkov and Mazei (2008), Kiss et al. (2009) and Camargo and Velho (2011).

On the other hand, there is no study so far on the effect of habitat structural complexity on the patterns of composition and richness of flagellate protozoa, as already performed for other organisms, like invertebrate and zooplankton (Beck, 1998; Kuczyńska-Kippen, 2007; Thomaz et al., 2008). The hypothesis that habitat complexity is positively related to the richness and diversity of species has been investigated since the 1960's (MacArthur and MacArthur, 1961). Theoretically, the more complex is a habitat the higher number of species it can sustain (Bell et al., 1991; Thomaz et al., 2008), because a more complex structure can favor the species coexistence, reduce the predation rates by increasing the number of refuges and shelters, reduce the competition for resources, and also enhance 
the foraging efficiency of species (MacArthur and MacArthur, 1961; Bell et al., 1991). However, this classical ecological premise had not been tested yet for all sorts of organisms, environments, and scales, given the several methodological difficulties to quantify the structural complexity in a judicious and reliable way (Taniguchi and Tokeshi, 2004).

In this context, this study aimed to: (I) contribute with the knowledge of patterns of spatial and seasonal distribution of composition and richness of planktonic flagellate protozoa in tropical impacted streams; (II) determine which type of variable (physical and chemical or habitat complexity descriptors) is more important for maintaining the structure of this community. To this end, we compared the species richness and community composition between rural and urban streams, in two seasons (summer and winter). We predicted that: (i) the spatial distribution of the species composition is regulated by the land use and occupation and its seasonal distribution, by the rainfall regime; and (ii) the number of species in the streams is primordially determined by the habitat's complexity, considering that more complex environments can sustain a greater number of species, independent of limnological conditions or seasonality of the rainfall regime.

\section{Material and Methods}

\subsection{Study area}

The Pirapó River watershed ( $22^{\circ} 30^{\prime} \mathrm{S}$ and $23^{\circ} 30^{\prime} \mathrm{S} ; 51^{\circ} 15^{\prime} \mathrm{W}$ and $52^{\circ} 15^{\prime} \mathrm{W}$ ) is located in the physiographic region of the Third Plateau of the Paraná State, Brazil. This watershed has a catchment area of about $5.076 \mathrm{~km}^{2}$ and it is under the influence of Maringá City, which is relatively industrialized and urbanized and considered the most important urban center in the region, with approximately 350.000 inhabitants. The streams studied are all first order (sensu Strahler, 1957) and are located in the surroundings of Maringá City (Figure 1), which has an extensive drainage network greatly modified by the land use and occupation.

The streams were categorized as rural (Água Queçaba, Água da Roseira, Remo, Romeira and Zaúna) or urban (Água do Pirapó, Guaiapó, Mandacarú, Miosótis and Nazaré), based on their location in the study area (Figure 1). In general, both in urban and rural streams were observed stretches greatly modified by human activities such as: clandestine disposal of domestic effluents and solid waste in the surroundings and on the bed of these streams (e.g. debris of construction materials, cans, plastic bottles, tires, old furniture, etc.), agricultural activities close to the riparian vegetation; deforestation of this vegetation, damming; channeling, sealing of the soil surrounding these streams, among others.

\subsection{Samplings and laboratory procedures}

Samplings were performed during summer (February 2008) and winter (July 2008). Each stream had three sampling locations (headwater, middle course and mouth), except for habitat descriptor variables, comprising 180 samples. The biological samples were obtained through passing a polyethylene flask (two liters) just under the water surface. The individuals were analyzed in vivo, under an optical microscope, according to Gasol (1993), to avoid alterations in the cell shape and dimension by the preservation process. The slides were analyzed until no new species was found. The species were identified, whenever possible, based on morphological characteristics and with specialized literature. The results were presented according to the classification system proposed by Lee et al. (2000).

Besides the biological samplings, the electrical conductivity, dissolved oxygen, $\mathrm{pH}$, depth, water temperature and current velocity were also measured, using portable equipments. The nitrate and phosphate concentrations were determined in laboratory, using the methods proposed by Golterman et al. (1978) and Zagatto et al. (1981).

The procedures for determining habitat complexity were based on the methods proposed by Hauer and Lamberti (1998), Matthews (1998) and Willis et al. (2005). The following variables were used as habitat complexity descriptors: current velocity, depth, substrate grain size, and habitat macrostructure, randomly measured (five replicates, $\mathrm{n}=1050)$ in seven transects ten meters along each region of the stream (headwater, middle course and mouth).

The substrate granulometer and habitat macrostructure were visually categorized (always by the same observer), using a quadrat, where the percentage cover values were used to estimate the frequency of occurrence (inside each quadrat area) of each item from each habitat descriptor variable. The items for the substrate granulometer variable were defined as silt, clay and sand $(<2 \mathrm{~mm})$, granule $(2-4 \mathrm{~mm})$, block (4-64 $\mathrm{mm})$, pebbles $(64-256 \mathrm{~mm})$ and flagstone/slab $(>256 \mathrm{~mm})$. The items for habitat macrostructure were classified as 


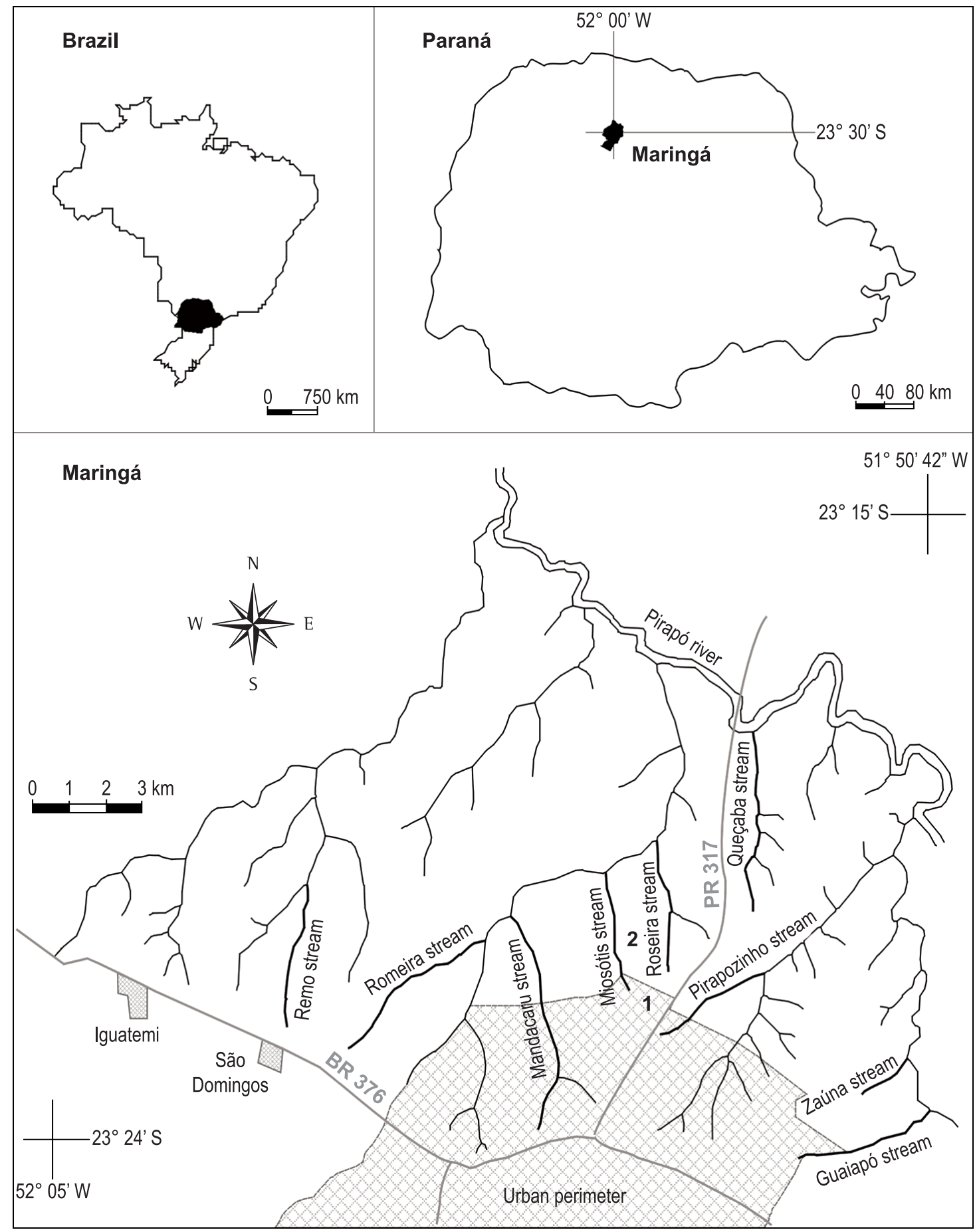

Figure 1. Location of the study area and sampled streams (indicated by names). Where: 1 . Urban perimeter; 2. Rural perimeter.

leaf, branch, root, trunk, aquatic macrophyte and artificial structure (cans, debris of construction material, plastic bottles, tires, and other items).

\subsection{Data analyses}

To characterize the streams and detect a possible environmental gradient, we applied a principal component analysis (PCA). Before this, values of frequency of occurrence (\%) of the items from the habitat descriptor variables (substrate granulometry and habitat macrostructure) were used to calculate the Shannon-Wiener diversity index (Shannon and Weaver, 1949) and infer how complex the environments were. This index was calculated by the equation $-\Sigma p i$. In.pi, where $\ln$ is the natural logarithm and $p i$ is the frequency 
of occurrence proportional of items (i), from each habitat descriptor variable. Subsequently, all abiotic variables (electrical conductivity, phosphate, substrate grain size, habitat macrostructure, nitrate, dissolved oxygen, $\mathrm{pH}$, depth, water temperature and current velocity) were summarized by the PCA, and the axes were retained for interpretation according to the Kaiser-Guttman criterion (Eigenvalues > 1.0) (Jackson, 1993).

Aiming to summarize graphically the patterns of spatial and seasonal distribution of species composition, it was used a multidimensional scaling analysis (MDS - Clarke and Warwick, 1994), which provides values of stress from 0 to 1 and express how much the graphic configuration proposed represents the data, thus, the lower the stress value the better data representation. To construct the similarity matrices, we used the Bray-Curtis coefficient, and to test if the composition and richness present significant patterns of spatial and seasonal distribution, it was employed a two-factors analysis of similarities (Two-Way ANOSIM - Clarke, 1993), which is a non-multivariate parametric test analogous to the analysis of variance, widely used to test ecological hypotheses (Clarke and Warwick, 1994).

In order to understand the influence of abiotic factors and variables of habitat complexity on the patterns of composition and richness of flagellate protozoa, we used the Bioenv analysis (Clarke and Warwick, 1994), which correlated a biotic data matrix with an environmental data matrix through a Spearman correlation (Clarke and Warwick, 1994). The final solution of this multivariate analysis is a model that better explains the variation of biological data as a function of abiotic ones. The statistical significance of the models selected by the Bioenv was tested by a Mantel Test (Mantel, 1967), with 1,000 randomizations, according to recommendations of Melo (2009).

For all these analyses, data were not transformed and the significance level was set at $\mathrm{p} \leq 0.05$. The analyses were run using the following softwares: Past (Two-Way ANOSIM), PC-ORD 6.0 (MDS), R 2.11.1 (Bioenv and Mantel Test) and Statistica 7.0 (graphs).

\section{Results}

\subsection{Environmental variables: environmental characterization and principal component analysis}

In general, the streams were shallow, with rapid current and well-structured beds (Table 1). They also had a slightly acidic $\mathrm{pH}$, high electrical conductivity and relatively low oxygen concentration, especially in urban streams (Table 1). These streams had higher concentrations of nitrate and phosphate than rural streams (Table 1).

To detect a possible environmental gradient, the biotic variables were summarized by a principal component analysis and the three first axes retained for interpretation explained $55 \%$ of the total data variability (Figure 2; Table 2). Nevertheless, the greater part of data variability $(41 \%)$ was explained by the first two axes, which showed only a trend of separation of environments and periods. Furthermore, limnological variables had seasonal distribution patterns more evident than spatial patterns (Figure 2; Table 2).

Table 1. Mean values and standard deviation of limnological variables $(n=180)$ and habitat descriptor variables from urban and rural streams during summer and winter $(\mathrm{n}=1050)$.

\begin{tabular}{|c|c|c|c|c|c|c|c|c|}
\hline \multirow{3}{*}{ Abiotic variables } & \multicolumn{4}{|c|}{ Rural } & \multicolumn{4}{|c|}{ Urban } \\
\hline & \multicolumn{2}{|c|}{ Winter } & \multicolumn{2}{|c|}{ Summer } & \multicolumn{2}{|c|}{ Winter } & \multicolumn{2}{|c|}{ Summer } \\
\hline & Mean & S.D. & Mean & S.D. & Mean & S.D. & Mean & S.D. \\
\hline \multicolumn{9}{|l|}{ Limnological Variables } \\
\hline Electrical conductivity $\left(\mu \mathrm{S} . \mathrm{Cm}^{-1}\right)$ & 124.42 & 35.65 & 123.77 & 30.59 & 189.36 & 61.17 & 208.03 & 67.26 \\
\hline Phosphate $\left(\mathrm{mg} \cdot \mathrm{L}^{-1}\right)$ & 0.06 & 0.03 & 0.07 & 0.08 & 0.09 & 0.06 & 0.13 & 0.12 \\
\hline Nitrate $\left(\mathrm{mg} \cdot \mathrm{L}^{-1}\right)$ & 1.25 & 0.54 & 1.10 & 0.58 & 5.69 & 2.41 & 5.41 & 2.36 \\
\hline Dissolved oxygen (mg. $\mathrm{L}^{-1}$ ) & 7.53 & 0.73 & 8.32 & 0.96 & 6.96 & 0.44 & 7.77 & 0.89 \\
\hline $\mathrm{pH}$ & 6.87 & 0.18 & 6.96 & 0.20 & 6.91 & 0.30 & 6.92 & 0.29 \\
\hline Water temperature $\left({ }^{\circ} \mathrm{C}\right)$ & 17.56 & 1.31 & 21.51 & 0.61 & 19.69 & 1.07 & 22.16 & 1.27 \\
\hline \multicolumn{9}{|l|}{ Habitat Descriptor Variables } \\
\hline Substrate grain size (nats.item ${ }^{-1}$ ) & 0.92 & 0.01 & 0.91 & 0.02 & 0.92 & 0.01 & 0.91 & 0.01 \\
\hline Habitat macrostructure (nats. item ${ }^{-1}$ ) & 0.75 & 0.06 & 0.69 & 0.13 & 0.63 & 0.19 & 0.62 & 0.18 \\
\hline Depth (m) & 0.18 & 0.05 & 0.18 & 0.07 & 0.22 & 0.10 & 0.19 & 0.07 \\
\hline Current velocity $\left(\mathrm{m} \mathrm{s}^{-1}\right)$ & 0.27 & 0.10 & 0.25 & 0.09 & 0.20 & 0.06 & 0.19 & 0.09 \\
\hline
\end{tabular}



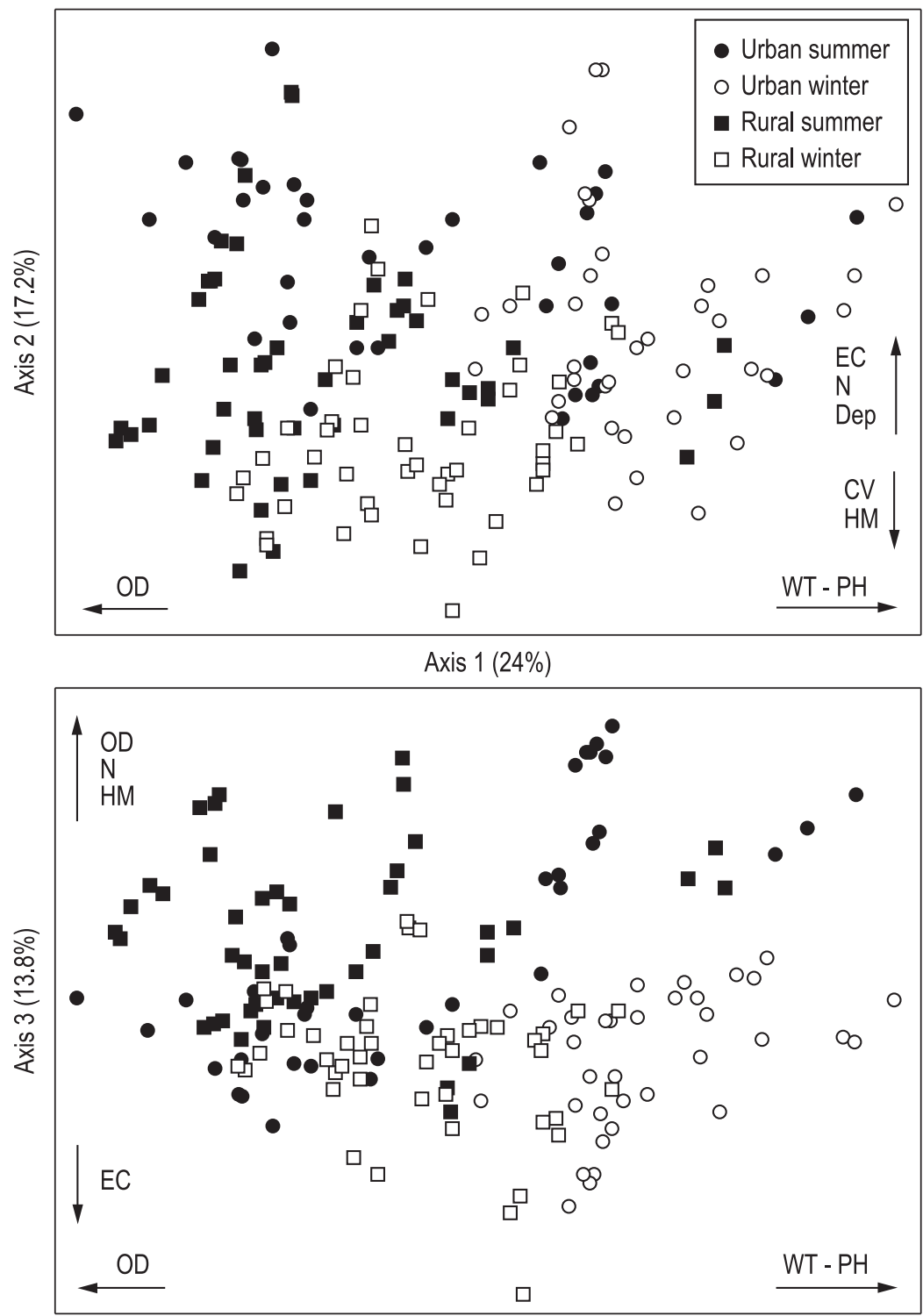

Axis $1(24 \%)$

Figure 2. Scores distribution along PCA axes performed with limnological variables and habitat variables of urban and rural streams during summer and winter (Where: $\mathrm{CV}$ = current velocity; Dep = depth; EC = electrical conductivity; $\mathrm{HM}=$ habitat macrostructure; $\mathrm{N}=$ nitrate; $\mathrm{OD}=$ dissolved oxygen; $\mathrm{PH}=$ potential of hydrogen and $\mathrm{WT}=$ water temperature).

The axis 1 described mainly the seasonal pattern of the variables, being positively influenced by $\mathrm{pH}$ and temperature and negatively influenced by availability of dissolved oxygen (Figure 2; Table 2). On the other hand, the axes 2 and 3 summarized mainly the spatial patterns of variables. The axis 2 was negatively influenced by the habitat macrostructure and current velocity, and positively by electrical conductivity, nitrate concentration and depth (Figure 2; Table 2). In turn, the axis 3 was positively influenced by the availability of dissolved oxygen, nitrate concentration and habitat macrostructure, and negatively, by electrical conductivity (Figure 2; Table 2).

\subsection{Species composition}

The flagellate protozoa community was represented by 106 taxa, belonging to nine orders and one residual group (made up by taxa without common phylogenetic origins). The observed orders were: Choanoflagellida (one taxon), Chromulinales (six taxa), Cryptomonadida (five taxa), Euglenida (71 taxa), Gymnodiniales (five taxa), Kinetoplastea (eight taxa), Peridiniales (two taxa), Synurales (two 
taxa) and Volvocida (six taxa). The Euglenida order was the most species-rich in all of the streams, during both periods studied (Figure 3) due to the contribution of Trachelomonas (16 taxa), Euglena (11 taxa) and Phacus (11 taxa). The multidimensional scaling analysis (MDS) indicated no clear distinction between streams and periods (Figure 4), only the trend for separation of three large groups, the first formed by species typical of rural streams, the second, by species typical of urban streams and the third, by species occurring in both streams, regardless of the period (Figure 4). Meanwhile, the analysis of similarities (Two-Way ANOSIM) pointed out significant differences between stream types $(\mathrm{R}=0.11 ; \mathrm{p}=0.0001)$, and between sampling periods $(\mathrm{R}=0.10 ; \mathrm{p}<0.0001)$.

\subsection{Species richness}

Species richness ranged between 1 and 22 taxa, with values between 1 and 10 taxa in urban areas and between 1 and 22 taxa in rural areas. The values ranged between 1 and 22 in winter and between 1 and 15 in summer. The highest species richness was recorded in rural streams during the winter (Figure 5). This pattern was corroborated by the Two-Way ANOSIM, which showed significant differences between both streams $(\mathrm{R}=0.10$; $\mathrm{p}=0.0004)$, and periods $(\mathrm{R}=0.10 ; \mathrm{p}<0.0001)$ (Figure 5).

\subsection{Influence of abiotic variables on species composition and species richness}

According to the Bioenv and Mantel test, the abiotic variables most important for the

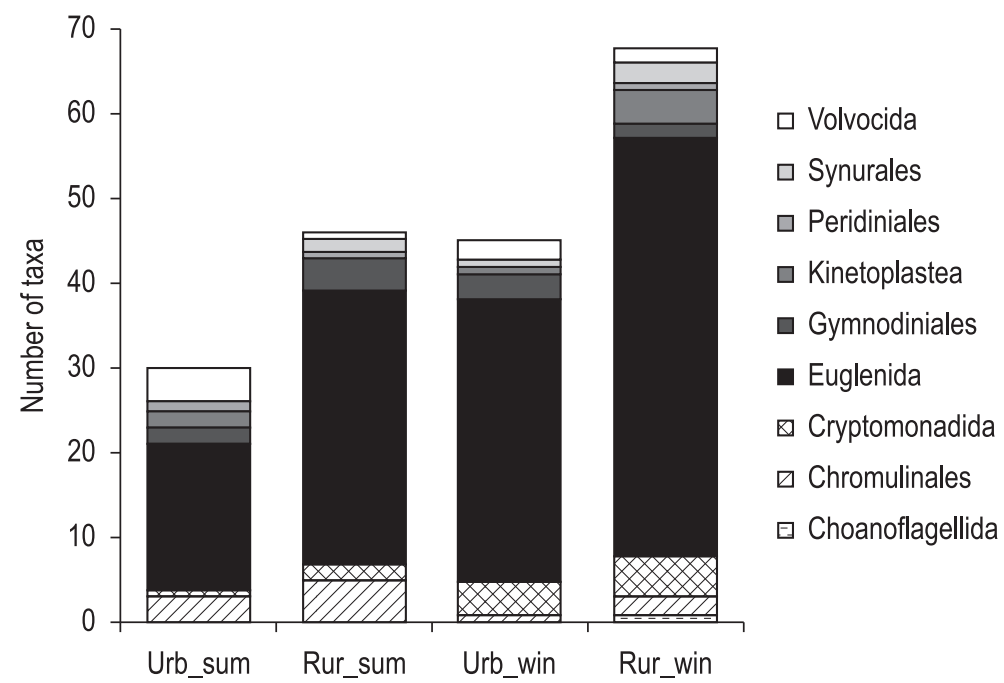

Figure 3. Species composition in the studied streams during two periods (Where: Urb_Sum: urban streams, summer; Rur_Sum: rural streams, summer; Urb_Win: urban streams, winter and Rur_Win: rural streams; winter).

Table 2. Variables that contributed most to the formation of axes, eigenvalues and percentage of explanation from a principal component analysis (PCA) applied to limnological variables and habitat descriptor variables of urban and rural streams during summer and winter.

\begin{tabular}{|c|c|c|c|}
\hline Variables & Axis 1 & Axis 2 & Axis 3 \\
\hline Electrical conductivity $\left(\mu \mathrm{S} . \mathrm{Cm}^{-1}\right)$ & 0.16 & 0.71 & -0.41 \\
\hline Phosphate (mg. $\left.\mathrm{L}^{-1}\right)$ & -0.19 & -0.25 & -0.38 \\
\hline $\mathrm{pH}$ & 0.94 & -0.20 & 0.17 \\
\hline Dissolved oxygen (mg. $\left.\mathrm{L}^{-1}\right)$ & -0.65 & 0.07 & 0.66 \\
\hline Nitrate $\left(m g \cdot L^{-1}\right)$ & 0.02 & 0.56 & 0.51 \\
\hline Water temperature $\left({ }^{\circ} \mathrm{C}\right)$ & 0.94 & -0.20 & 0.16 \\
\hline Substrate grain size (nats.item ${ }^{-1}$ ) & 0.14 & -0.08 & -0.02 \\
\hline Habitat macrostructure (nats. item $^{-1}$ ) & -0.03 & -0.57 & 0.47 \\
\hline Depth (m) & 0.26 & 0.44 & 0.30 \\
\hline Current velocity $\left(\mathrm{m} . \mathrm{S}^{-1}\right)$ & -0.27 & -0.49 & -0.12 \\
\hline Explanation \% & 24.0 & 17.2 & 13.8 \\
\hline Eigenvalues & 2.40 & 1.72 & 1.38 \\
\hline
\end{tabular}




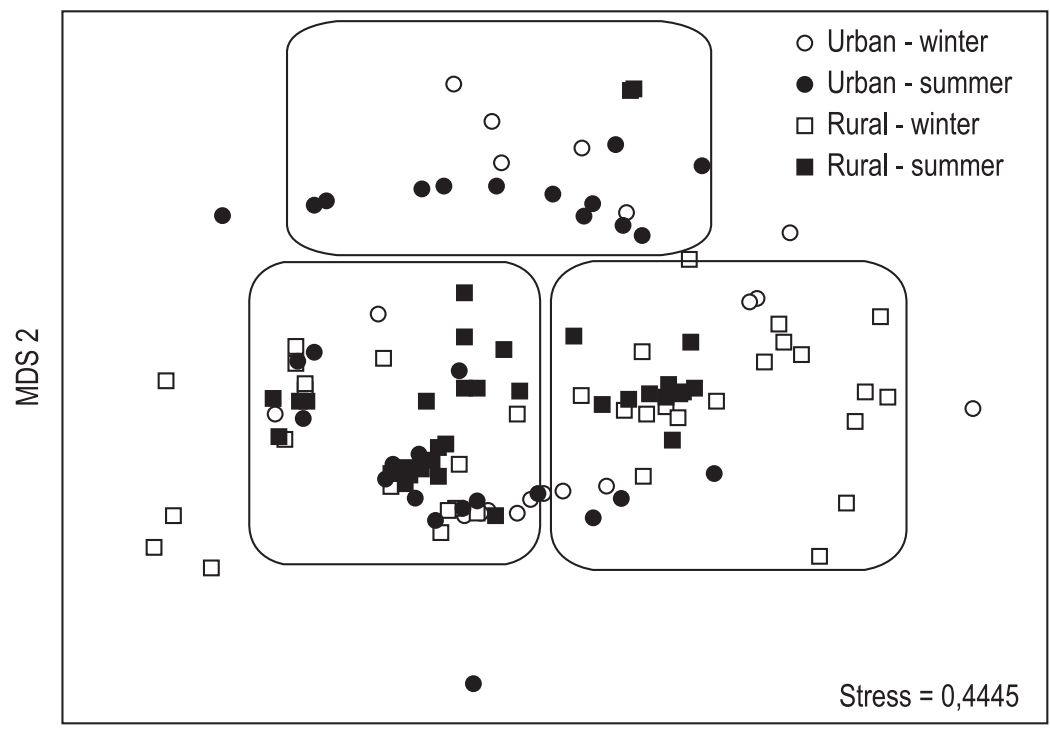

MDS 1

Figure 4. Ordination of the composition of flagellate protozoa species according to the MDS, performed with data of presence and absence of flagellate protozoa collected in 10 tropical streams ( 5 urban and 5 rural), in two seasons (winter and summer).
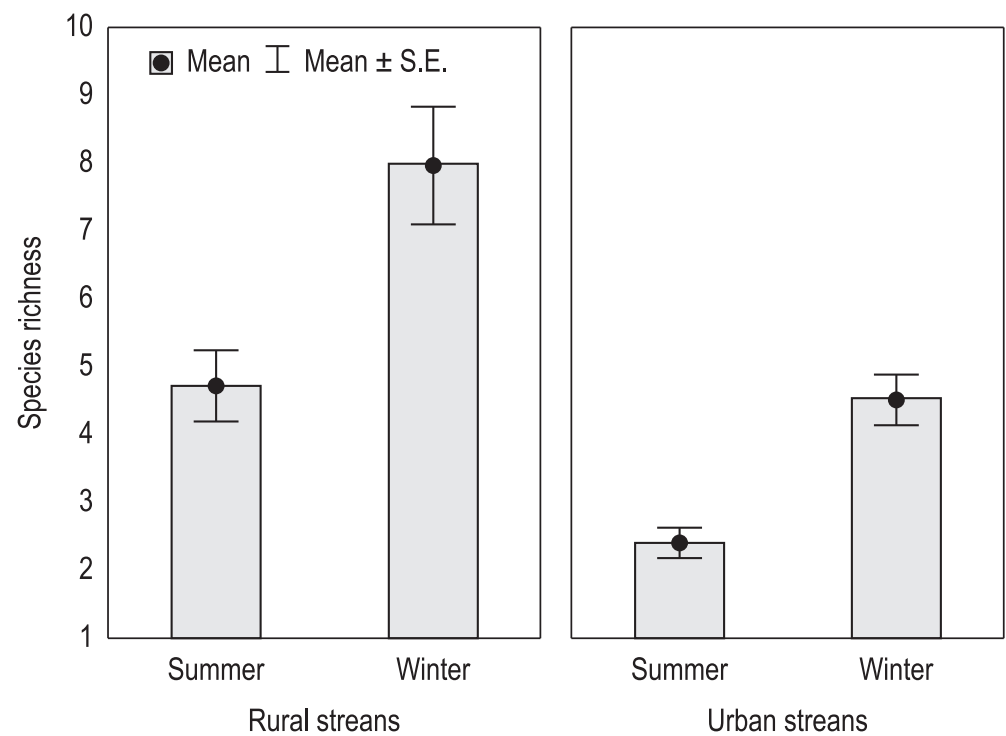

Figure 5. Spatial and seasonal variation of flagellate protozoa species in 10 streams ( 5 urban and 5 rural), in two seasons (summer and winter).

structure of flagellate protozoa community in the studied streams were electrical conductivity, total phosphorus, $\mathrm{pH}$, total nitrogen, and habitat macrostructure. The species composition was specifically influenced by electrical conductivity, total phosphorus, $\mathrm{pH}$, total nitrogen $\left(\mathrm{R}_{[\text {Bioenv }]}=0.18\right.$; $\left.\mathrm{R}_{[\text {Mantel] }}=0.17 ; \mathrm{p}_{[\text {Mantel] }}=0.002\right)$, whereas the species richness, by all these limnological variables and even by the habitat macrostructure $\left(\mathrm{R}_{[\text {Bioenv }]}=0.17\right.$; $\left.\mathrm{R}_{[\text {Mantel] }}=0.17 ; \mathrm{p}_{[\text {Mantel }]}=0.04\right)$.

\section{Discussion}

\subsection{Patterns of spatial and seasonal distribution of species composition}

Although flagellate protozoa play an important role in the carbon cycle in aquatic ecosystems, ecological researches with these organisms usually do not have any taxonomic detail (Arndt et al., 2000). According to this author, the identification of flagellate species becomes more difficult when 
they do not possess a rigid body owing the lack of lorica, because the fixation techniques cause cell deformations and thus hinder the identification of taxa. Despite this difficulty, this study has identified 106 taxa and great part of the species composition belongs to the order Euglenida, responsible for $65 \%$ of total species identified. Euglenids are good indicators of pollution (Palmer, 1969) and the great success of this group in the studied streams can be attributed to their preferences for environments with more acidic waters and rich in organic matter and ammonia (Lee et al., 2000; Reynolds et al., 2002).

The pattern of species composition herein registered is different from others found in lotic environments, especially those located in temperate regions (Arndt and Mathes, 1991; Weitere and Arndt, 2003; Tikhonenkov and Mazei, 2006, 2008; Kosolapova, 2007; Kiss et al., 2009). In most of these environments, there was a predominance of Chrysomonadida and in general the species Spumella is the most common and abundant (Arndt and Mathes; 1991; Weitere and Arndt, 2003; Kiss et al., 2009). These differences can be related to the climate, latitude and especially to methodological procedures, once these authors have considered only heterotrophic flagellates and the present study considered this community as a whole, evaluating the heterotrophic, mixotrophic and autotrophic fractions. The studies that have considered all fractions (Carlough and Meyer, 1989; Araújo and Godinho, 2008; Camargo and Velho, 2011) presented composition patterns more similar to the observed in this study, with an expressive qualitative contribution of euglenids.

The results of the Two-Way ANOSIM and MDS revealed that the species composition had significant patterns of spatial and seasonal distribution. This shows the existence of species replacement between streams and periods. But the MDS diagram demonstrated that only a part of species should have been replaced over time and space in response to changes in environmental conditions, because many flagellate had a wide distribution, occurring in all locations and periods. This assertion is strengthened by the three clusters in the MDS diagram, with the first formed by species typical of rural streams, in the winter or summer, the second, by species characteristic of urban streams in the winter or summer, and the third group made up by species common to both periods and stream types (high beta diversity). Besides that, the MDS also indicated that the patterns of spatial distribution of the composition seem to be more evident than seasonal patterns. This result suggests that human impacts from the land use and occupation are more important than the seasonality of the rainfall regime to determine the occurrence of flagellate species in the studied streams.

The results of the Bioenv and Mantel test corroborated this affirmation, since they showed that the species composition of flagellate was especially influenced by limnological variables describing the water quality, such as the electrical conductivity, $\mathrm{pH}$, nitrogen and phosphorus. It is important to emphasize that great part of nutrients, ions, sediments and organic matter flowing into a stream arises from environmental disturbances caused by human occupation in the watershed (Pinto and Cavalcanti, 2001). Therefore, the water quality seems to be the most important factor for the structure of flagellate community composition in tropical streams under direct urban influence. The urbanization effects on lotic environments are so adverse that has been called in recent years as urban stream syndrome (Meyer et al., 2005). This syndrome describes a set of symptom common to lotic ecosystems under a series of alterations in their structure and metabolism, such as changes in hydrology, channel morphology, waterproofing of the watershed, increase in concentration of nutrients and contaminants, changes in $\mathrm{pH}$, increase in concentration of ions, reduction in species richness along with increased dominance of taxa tolerant to environmental disturbances, among others (Meyer et al., 2005; Walsh et al., 2005).

Among these symptoms, the most important for regulating the patterns of flagellate composition in studied streams were the higher concentrations of nitrogen and phosphorus, acidification of the $\mathrm{pH}$, and increased electrical conductivity. The effect of increasing the levels of nutrients on protozoans had already been recognized in several freshwater ecosystems (Pace and Funke, 1991; Weisse, 1991; Mathes and Arndt, 1994; Gasol et al., 1995; Hwang and Heath, 1997). The direct and/or indirect immediate consequences of this increase on flagellates are the increase in abundance and biomass given the expansion of their food resources (especially bacteria and nanophytoplankton) and changes in biotic interactions with other components of microbial chains (Auer et al., 2004). The effects of the extra input of nutrients on the species composition of flagellate have been little investigated, and up to now only non-significant trends have been reported in 
the species composition as a function of increased environmental trophy (Carrick and Fahnenstiel, 1989; Auer et al., 2004). However, our results showed that the increase in nutrient concentrations promotes significant changes in the composition and richness of flagellate species in tropical lotic impacted environments, corroborating in this way the trends observed in other studies.

Other important abiotic factors that have limited the distribution of flagellate in the streams were the high values of electrical conductivity and slightly acidic $\mathrm{pH}$. In general, these two parameters may also indicate with accuracy the water quality (Esteves, 1998). According to this author, high values of electrical conductivity reveal sources of organic pollution in the water body. And low $\mathrm{pH}$ values can be caused by the organic matter decay in the environment; the greater amount of available organic matter the lower the $\mathrm{pH}$, once to occur decay of organic matter, several acids are produced (e.g. humic acid) Maier, 1987). In agreement with Ardnt et al. (2000), the tolerance ranges of flagellate species for abiotic conditions are unknown and neglected, hindering the determination of the best range. Nevertheless, the results pointed out that in tropical lotic environments, flagellate do not adapt very well to the values of electrical conductivity above $180 \mu \mathrm{S} . \mathrm{Cm}^{-1}$ and $\mathrm{pH}$ below 6 .

On the other hand, although the patterns of spatial distribution had been much more evident, seasonal differences observed for the species composition can be assigned to the hydrological instability in the summer, caused by characteristic rainfall as previously predicted. Rainfall work as agents disturbing the structure, dynamics, and metabolism of the environment and biota because promotes the wash-out of the allochthonous material from terrestrial origin, increase the turbidity, trigger changes in the nutrient concentration, favor heterotrophic processes, erode the bed, and displace many organisms from their microhabitats (Cushing and Allan, 2001). Thus in this period, only species more adapted to these adverse conditions can stay in the environment, which possibly explains the replacement of species over the periods analyzed.

In this way, our results corroborated the first hypothesis, considering that spatial differences in species composition were probably regulated by the land use and occupation, and seasonal differences, by the rainfall regime. These results also indicated that this community is highly sensitive to environmental changes and can be used as an efficient bioindicators of water quality, as already performed with ciliate protozoa (Foissner, 1997; Madoni and Bassanini, 1999; for instance). However to prevent classical problems of species identification, it is also recommended the use of molecular taxonomy, which has becoming an important tool to help the traditional taxonomy in the identification of species with difficult taxonomic classification, or for groups that have little effective morphological identification techniques. For this it is necessary investments for the acquisition of new equipments and training of specialized staff to develop this technique, which is not yet widespread in all research centers because of these prerequisites.

\subsection{Patterns of spatial and seasonal distribution of species richness}

Although some authors draw criticism to the subjectivity of the concept of habitat complexity, the methods applied to obtain measures of spatial heterogeneity and scales of environmental perception by organisms (Beck, 1998; Thomaz et al., 2008), our results revealed a positive relationship between flagellate species richness and habitat macrostructure. Several studies undertaken with other communities have already observed that the habitat structural complexity exerts influences on the number of species (MacArthur and MacArthur, 1961; Taniguchi and Tokeshi, 2004; Willis et al., 2005; Thomaz et al., 2008). In theory, physically more complex habitats can contain more species because they provide several advantages to the organisms (Bell et al., 1991). In the case of lotic environments, submerged structures (rocks, branches, leaves, roots, macrophytes, among others) create microhabitats used as refuges against predators and the direct incidence of the water flow (Allan, 1995; Giller and Malmquist, 1998), ease the species coexistence due to the niche partitioning (MacArthur and MacArthur, 1961), provide surfaces for the deposition of organic debris and for the colonization of a rich associated fauna (bacteria, algae, fungi, and invertebrate) and then increase the supply of food resources for the organisms

But unlike the predicted before, the number of species of flagellate was not exclusively determined by the habitat structural complexity, it was also influenced by physical and chemical conditions of the water (the same that influenced the species composition) of the studied streams. In this way, the second hypothesis is rejected, once the alterations in the water quality have also determined the number of species in the streams. Thus, differences in the number of species between streams should have 
be supported by the deterioration of water quality and by the simplification of habitats observed in urban streams, which presented the lowest richness compared with the rural streams. On the other hand, the seasonal variation of this attribute can be especially ascribed to the loss of stability of the structural arrangement of the habitat caused by the wash-out effect of the rainfall, considered modifying agents of the shape, type and size of submerged structures in the beds of streams (Allan, 1995; Giller and Malmquist, 1998; Fiona et al., 2006). Therefore, the highest richness recorded in the winter may be related to the typical lack of rainfall in this period.

The comparison of these patterns of richness is precluded by the scarcity of studies on the number of flagellate species in other lotic environments; the majority had no taxonomic detail or separated flagellates into large taxonomic groups. However, comparing the results with the few data available in literature (65 species in the Rhine River, Germany - Weitere and Arndt, 2003; 99 species in the Chernaya River, Russia - Tikhonenkov and Mazei, 2006; 29 species in the Latka River, Russia - Kosolapova, 2007; 41 species in eight rivers located in Abkhazia, Brazil, China and Russia - Tikhonenkov and Mazei, 2008; 30 species in the Pitimbu River, Brazil - Araújo and Godinho, 2008 and 70 species in the Danube River, Hungary - Kiss et al., 2009), we may observe that the flagellate community in the studied streams is quite rich and presents richness values higher than found in other lotic environments. This difference can be especially associated with methodological procedures adopted, once most of these researches have approached only the heterotrophic fraction of the flagellate community. Even though, it cannot be disregarded the effect of climate and latitude on the patterns of richness, because these factors certainly may have contributed with the differences observed between these environments. Importantly, the number of flagellate species in tropical environments should be higher than known, making necessary the completion of further studies to survey all these taxa.

In summary, the results obtained showed that the number of flagellate species in the studied streams depend on the water quality and stability of the habitat structural complexity, which can be disturbed by the rainfall regime. Moreover, changes in the channel morphology caused by human activities may imply in loss of flagellate species due to the simplification of the habitat structure.
This finding represents relevant information for the management of lotic environments inserted in urban landscapes, because this pattern certainly should be found in other aquatic communities inhabiting anthropized lotic environments. Meanwhile, to be more effective the management of these ecosystems should adopt a broader perspective of intervention, including human populations that use these environments as an environmental resource, considering their social, economic and political scopes, as only so there will be an effective reduction of conflicts and of social and environmental impacts (Walsh et al., 2005).

\section{Acknowledgements}

We would like to thank the Brazilian National Research Council (CNPq) for financial support and for granting a master degree scholarship. We also thank the Research Nucleus in Limnology, Ichthyology and Aquaculture (Nupélia) of State University of Maringá (UEM) for the infrastructure and logistical support.

\section{References}

ALLAN, JD. 1995. Stream Ecology. London: Chapman and Hall. 388 p.

ARAÚJO, MFF. and GODINHO, MJL. 2008. Spatial and seasonal variations of planktonic protists (Mastigophora, Sarcodina and Ciliophora) in a river-lacustrine system in northeast Brazil. Acta Limnologica Brasiliensia, vol. 20, no. 3, p. 235-244.

ARNDT, H. 1993. Rotifers as predators on components of the microbial web (bacteria, heterotrophic flagellates, ciliates) - a review. Hydrobiologia, vol. 255, p. 231-246. http://dx.doi.org/10.1007/BF00025844

ARNDT, H. and MATHES, J. 1991. Large heterotrophic Flagellates form a significant part of protozooplankton biomass in lakes and rivers. Ophelia, vol. 33, no. 3, p. 225-234. http://dx.doi.org/10.1080/00785326. 1991.10429713

ARNDT, H., DIETRICH, D. and AUER, B. 2000. Functional diversity of heterotrophic flagellates in aquatic ecosystems. In LEADBEATER, BSC. and GREEN, JC., orgs. The Flagellates. London: Taylor and Francis. p. 240-268.

AUER, B. and ARNDT, H. 2001. Taxonomic composition and biomass of heterotrophic flagellates in relation to lake trophy and season. Freshwater Biology, vol. 46, p. 959-972. http://dx.doi.org/10.1046/j.13652427.2001.00730.x

AUER, B., ELZER, U. and ARNDT, H. 2004. Comparison of pelagic food webs in lakes along a trophic gradient and with seasonal aspects: influence of resource and predation. Journal of Plankton 
Research, vol. 26, no. 6, p. 697-709. http://dx.doi. org/10.1093/plankt/fbh058

AZAM, F., FENCHEL, T., FIELD, JG., GRAY, JS., MEYER-REIL, LA. and THINGSTAD, F. 1983. The ecological role of water column microbes in the sea. Marine Ecology Progress Series, no. 10, p. 257-263. http://dx.doi.org/10.3354/meps010257

BECK, MW. 1998. Comparison of the measurement and effects of habitat structure on gastropods in rocky intertidal and mangrove habitats. Marine Ecology Progress Series, vol. 169, p. 165-178. http://dx.doi. org/10.3354/meps169165

BELL, SS., McCOY, ED. and MUSHINSKY, HR. 1991. Habitat Structure: The physical arrangement of objects in space. London: Chapman and Hall. 438 p. http://dx.doi.org/10.1007/978-94-011-30769_12

CAMARGO, JC. and VELHO, LFM. 2011. Longitudinal variation of attributes from flagellate protozoan community in tropical streams. Acta Scientiarum. Biological Sciences, vol. 33, no. 2, p. 161-169. http:// dx.doi.org/10.4025/actascibiolsci.v33i2.7228

CARLOUGH, L. and MEYER, JL. 1989. Protozoans in two southeastern blackwater rivers and their importance to trophic transfers. Limnology and Oceanography, vol. 34, no. 1, p. 163-177. http:// dx.doi.org/10.4319/lo.1989.34.1.0163

CARRICK, HJ. and FAHNENSTIEL, GL. 1989. Biomass, size distribution, and composition of phototrophic and heterotrophic nanoflagellate communities in Lakes Horon and Michigan. Canadian Journal of Fisheries and Aquatic Sciences, vol. 46, no. 11, p. 1922-1928. http://dx.doi. org/10.1139/f89-242

CLARKE, KR. 1993. Non-parametric multivariate analysis of changes in community structure. Australian Journal of Ecology, vol. 18, no. 1, p. 117-143. http:// dx.doi.org/10.1111/j.1442-9993.1993.tb00438.x

CLARKE, KR. and WARWICK, RM. 1994. Change in marine communities: an approach to statistical analysis and interpretation. Plymouth: Plymouth Marine Laboratory. $144 \mathrm{p}$.

CUSHING, CE. and ALLAN, JD. 2001. Streams: Their ecology and life. San Diego: Academic Press. http:// dx.doi.org/10.1016/B978-012050340-7/50007-8

ESTEVES, FA. 1998. Fundamentos de limnologia. Rio de Janeiro: Interciência Ltda. 602 p.

FIONA, JMS., STUART, EB. and ALAN, PNH. 2006. Habitat dynamics in the bed sediments of an intermittent upland stream. Aquatic Science, vol. 68, no. 1, p. 86-99.

FOISSNER, W. 1997. Protozoa as bioindicators in agroecosystems, with emphasis on farming practices, biocides, and biodiversity. Agriculture, Ecosystems and Environment, vol. 62, no. 2-3, p. 93-103. http:// dx.doi.org/10.1016/S0167-8809(96)01142-5
GASOL, JM. 1993. Benthic Flagellates and ciliates in fine freshwater sediments: calibration of a live counting procedure and estimation of their abundances. Microbial Ecology, vol. 25, no. 3, p. 247-262. http:// dx.doi.org/10.1007/BF00171891

GASOL, JM., SIMONS, AM. and KALFF, J. 1995. Patterns in the top-down versus bottom-up regulation of heterotrophic flagellates in temperate lakes. Journal of Plankton Research, Vol. 17, no. 10, p. 1879-1903. http://dx.doi.org/10.1093/plankt/17.10.1879

GILLER, PS. and MALMQVIST, B. 1998. The biology of streams and rivers. New York: Oxford University Press. 296 p.

GOLTERMAN, HL., CLYMO, RS. and OHNSTAD, MAM. 1978. Methods for physical and chemical analysis of freshwater. London: Blackwel Science Publications. 213 p.

HAUER, FR. and LAMBERTI, GA. 1998. Methods in stream ecology. San Diego: Academic Press. 877 p.

HWANG, SJ. and HEATH, RT. 1997. The distribution of protozoa across a trophic gradient, factors controlling their abundance and importance in the plankton food web. Journal of Plankton Research, vol. 19, no. 4, p. 491-518. http://dx.doi. org/10.1093/plankt/19.4.491

JACKSON, DA. 1993. Stopping rules in principal components analysis: Comparison of heuristical and statistical approaches. Ecology, vol. 74, no. 8, p. 2204-2214. http://dx.doi.org/10.2307/1939574

JIANG, JG. and SHEN, YF. 2005. Use of the aquatic protozoa to formulate a community biotic index for an urban water system. Science of the Total Environment, vol. 346, no. 1-3, p. 99-111. http:// dx.doi.org/10.1016/j.scitotenv.2004.12.001

KISS, AK., ÁCS, E., KISS, KT. and TÖRÖK, JK. 2009. Structure and seasonal dynamics of the protozoan community (heterotrophic flagellates, ciliates, amoeboid protozoa) in the plankton of a large river (River Danube, Hungary). European Journal of Protistology, vol. 45, no. 2, p.121-138. http://dx.doi. org/10.1016/j.ejop.2008.08.002

KOSOLAPOVA, NG. 2007. Quantitative distribution and taxonomic structure of the community of heterotrophic flagellates in the main biotopes of a Small Plain River. Hydrobiological Journal. vol. 43, no. 5, p. 55-63. http://dx.doi.org/10.1615/HydrobJ. v43.i5.30

KUCZYŃSKA-KIPPEN, N. 2007. Habitat choice in Rotifera communities of three shallow lakes: impact of macrophyte substratum and season. Hydrobiologia, vol. 593, no. 1, p. 27-37. http://dx.doi.org/10.1007/ s10750-007-9073-6

LEE, JJ., LEEDALE, GF. and BRADBURY, P. 2000. Illustrated guide to the Protozoa. 2nd ed. Kansas: Society of Protozoologists. 1432 p. 
MacARTHUR, RH. and MacARTHUR, JW. 1961. On bird species diversity. Ecology v. 42, p. 317-323. http://dx.doi.org/10.2307/1932254

MADONI, P. and BASSANINI, N. 1999. Longitudinal changes in the ciliated protozoa communities along a fluvial system polluted by organic matter. European Journal of Protistology, vol. 35, no. 4, p. 391-402. http://dx.doi.org/10.1016/S0932-4739(99)80048-0

MAIER, MH. 1987. Ecologia da bacia do Rio JacaréPepira (47055'-48 55'W; 22030'-21055'S - Brasil). Qualidade da água do Rio Principal. Ciência \& Cultura, vol. 39, no. 2, p.164-185.

MANTEL, N. 1967. The detection of disease clustering and generalized regression approach. Cancer Research, vol. 27, no. 2, p. 209-220. PMid:6018555.

MATHES, J. and ARNDT, H. 1994. Biomass and composition of protozooplankton in relation to lake trophy in north German lakes. Marine Microbial Food Webs, vol. 8, p. 357-375.

MATTHEWS, WJ. 1998. Patterns in Freshwater Fish Ecology. New York: Chapman and Hall, 756 p. http:// dx.doi.org/10.1007/978-1-4615-4066-3

MELO, AS. 2009. Explaining dissimilarities in macroinvertebrate assemblages among stream sites using environmental variables. Zoologia, vol. 26, no. 1, p. 79-84. http://dx.doi.org/10.1590/S198446702009000100013

MEYER, JL., PAUL, MJ. and TAULBEE, WK. 2005. Stream ecosystem function in urbanizing landscapes. Journal of the North American Benthological Society, vol. 24, no. 3, p. 602-612. http://dx.doi. org/10.1899/04-021.1

PACE, ML. and FUNKE, E. 1991. Regulation of planktonic microbial communities by nutrients and herbivores. Ecology, vol. 72, no. 3, p. 904-914. http:// dx.doi.org/10.2307/1940592

PALMER, CP. 1969. A composite rating of algae tolerating organic pollution. Journal Phycology, vol. 5, no. 1, p. 78-82. http://dx.doi. org/10.1111/j.1529-8817.1969.tb02581.x

PINTO, MAT. and CAVALCANTI, CGB. 2001. Uso e ocupação do solo e a qualidade das águas. In Fonseca, FO., ed. Olhares sobre o Lago Paranoá. Brasília: Secretaria do Meio Ambiente e dos Recursos Hídricos. p. 264-271.

REYNOLDS, CS., HUSZAR, V., KRUK, C., NASELLI-FLORES, L. and MELO, S. 2002. Towards a functional classification of the freshwater phytoplankton. Journal of Plankton Research, vol. 24, no. 5, p. 417-428. http://dx.doi.org/10.1093/ plankt/24.5.417

SAFI, KA. and HALL, JA. 1997. Factors influencing autotrophic and heterotrophic nanoflagellate abundance in five water masses surrouding. New Zealand. Journal of Marine and Freshwater Research, v. 31, n. 1, p. 51-60. http://dx.doi.org/10.1080/00 288330.1997.9516744

SAMUELSSON, K., BERGLUND, J. and ANDERSSON, A. 2006. Factors structuring the heterotrophic flagellate and ciliate community along brackish water primary production gradient. Journal of Plankton Research, vol. 28, no. 4, p. 345-359. http://dx.doi.org/10.1093/plankt/fbi118

SHANNON, CE. and WEAVER, W. 1949. The mathematical theory of communication. Urbana: University of Illinois Press. $117 \mathrm{p}$.

STRAHLER, AN. 1957. Quantitative analysis of watershed geomorphology. Transactions - American Geophysical Union, vol. 38, no. 6, p. 913-920.

TANIGUCHI, H. and TOKESHI, M. 2004. Effects of habitat complexity on benthic assemblages in a variable environment. Freshwater Biology, vol. 49, no. 9, p. 1164-1178. http://dx.doi.org/10.1111/ j.1365-2427.2004.01257.x

THOMAZ, SM., DIBBLE, E., EVANGELISTA, LR., HIGUTI, J. and BINI, LM. 2008. Influence of aquatic macrophyte habitat complexity on invertebrate abundance and richness in tropical lagoons. Freshwater Biology, v. 53, no. 2, p. 358-367.

TIKHONENKOV, DV. and MAZEI, YA. 2006. Distribution of Heterotrophic Flagellates at the Littoral of Estuary of Chernaya River (Kandalaksha Bay, White Sea). Russian Journal of Marine Biology, vol. 32, no. 5, p. 276-283. http://dx.doi.org/10.1134/ S1063074006050026

TIKHONENKOV, DV. and MAZEI, YA. 2008. Heterotrophic Flagellate Biodiversity and Community Structure in Freshwater Streams. Inland Water Biology, vol. 1, no. 2, p. 129-133. http://dx.doi. org/10.1134/S1995082908020041

WALSH, CJ., ROY, AH., FEMINELLA, JW., COTTINGHAM, PD., GROFFMAN, PM. and MORGAN, RP. 2005. The urban stream syndrome: current knowledge and the search for a cure. Journal of the North American Benthological Society, vol. 24, no. 3, p. 706-723. http://dx.doi.org/10.1899/04028.1

WEISSE, T. 1990. Trophic interactions among heterotrophic microplankton, nanoplankton, and bacteria in Lake Constance. Hydrobiologia, vol. 191, no. 1, p. 111-122. http://dx.doi.org/10.1007/ BF00026045

WEISSE, T. 1991. The microbial food web and its sensitivity to eutrophication and contaminant enrichment: a cross-system overview. Internationale Revue der Gesamten Hydrobiologie, vol. 76, no. 3, p. 327-337. http://dx.doi.org/10.1002/ iroh. 19910760305

WEITERE, M. and ARNDT, H. 2003. Structure of the heterotrophic flagellate community in water column of the River Rhine (Germany). European Journal of 
Protistology, v. 39, n. 3, p. 287-300. http://dx.doi. org/10.1078/0932-4739-00913

WILLIS, SC., WINEMILLER, KO. and LOPEZFERNANDEZ, H. 2005. Habitat structural complexity and morphological diversity of fish assemblages in a Neotropical river. Oecologia, vol. 142, no. 2, p. 284-295. http://dx.doi.org/10.1007/ s00442-004-1723-z

XU, M., CAO, H., XIE, P., DENG, D., FENG, W. and XU, J. 2005. The temporal and spatial distribution, composition and abundance of Protozoa in Chaohu
Lake, China: Relationship with eutrophication. European Journal of Protistology, vol. 41, no. 3, p. 183-192. http://dx.doi.org/10.1016/j. ejop.2005.03.001

ZAGATTO, EAG., JACINTHO, AO., REIS, BF., KRUG, FJ., BERGAMIN-FILHO, H., PESSENDA, LCR., MORTATTI, J. and GINÉ, MF. 1981. Manual de análise de plantas e águas empregando sistemas de injeção em fluxo. Piracicaba: CENA/USP. vol. 1, 35 p. http://dx.doi.org/10.1016/S00032670(01)83174-3

Received: 03 January 2012

Accepted: 04 October 2012 